\title{
"Nomenclature changes, essence unchanged": Peripheral prisons reform and refusal to alter deterrence for rehabilitation
}

Babatope Matthew Ajiboye

Department of Peace and Conflict Studies, Faculty of Social Sciences, Federal University Oye-Ekiti, Nigeria

Email: babatope.ajiboye@fuoye.edu.ng

Olabambo Evelyn Akinyemi

Department of Peace and Conflict Studies, Faculty of Social Sciences, Federal University Oye-Ekiti, Nigeria

Email: olabambo.satimehin@fuoye.edu.ng

Ene Norah Awe

Department of Peace and Conflict Studies, Faculty of Social Sciences, Federal University Oye-Ekiti, Nigeria

Email: ene.awe@fuoye.edu.ng

\begin{abstract}
The study focused on the Nigerian correctional institution and its mandate at rehabilitating convicts in preparedness for life outside bar and by implication reintegrating reformed individuals who are believed to pose no further threat to serenity of the society. Nigerian Correctional Service, previously known as Nigerian Prison Service, like its peer institution in the world, is primarily saddled with the responsibility to correct and reform convicts with the intent of reintegration back to conventional society. However, in Nigeria, this idea is
\end{abstract}


render null and void with the broad-spectrum conception that when a person is sentenced to serve a jail term, that ultimately signifies the end of his or her worth in the society. Hence, the paper interrogates the Nigerian Correctional Service as an institution vested with the priority of making convicts better individuals. Emphasis was placed on the purported reformation of the institution in 2019. A secondary source was used for data collection and the content analytical approach was adopted which led to inferences drawn and logical conclusion established. The work reveals problems of welfare, infrastructural decay, and congestion coupled with pseudo rehabilitation obtainable in the institution. The study recommends that the Nigerian criminal justice system deserve an overhaul.

Keywords: Nomenclature, Essence, Prison Reform, Deterrence, Rehabilitation

\section{Introduction}

The correctional establishment is not only an integral part of the society but also a social institution designed to regulate, regiment and tame the excessiveness of convicts who have been sentenced to serve a jail term as a result of been found guilty of an offence by a court of competent jurisdiction. It is worth noting that these punishments are not arrived at haphazardly, in short, it is a rigmarole process that has to follow the logical pattern of law stipulated. Following a chain of logical process is presumably done to at least avail the accused the opportunity of proofing his or her innocence as against the accusation levied against his or her personality. As one would expect, the cases could either fall into civil or criminal cases. However, as an establishment, Nigerian Correctional Service (NCS) is created mainly to reform convicted people and make them better individuals for society. In essence, the whole idea of incarceration and the number of times confined in the correctional centers are not only devoted to punishment but in a way meant to serve as a learning curve for the convicts in preparation for reintegration back to society. In the words of former United States Chief Justice, Warren Burger (1995 cited in Shajobi-Ibikunle, 2014:98) argued that 'to put people behind walls and bars and do little or nothing to change is to win a battle but lose a war'. He observed further that 'it was not only wrong but also costly and dim-witted'.

Nigeria as an organized society has the institution named Nigeria Correctional Service (NCS) formerly known as the Nigerian Prison Service 
(NPS), like what operates elsewhere in the world; it is vested with the authority to correct, reform and debug its citizens who have run foul of the law or committed offences that carry jail punishment. Obioha (2011:95) wittingly put that the main aim of establishing prison institutions in all parts of the world including Nigeria is to provide a rehabilitation and correctional facility for those who have violated the rules, and regulations of their society. The reformation and rehabilitation of convicts is captured by the Nigerian Correctional Service Act, 2019. According to Part 1, Section 14 subsections (1) and (2) of the Act, 'the Correctional Service shall provide opportunities for education, vocational training, as well as training in modern farming techniques and animal husbandry for inmates'. Subsection (2) holds that, following the provisions of subsection (1), Correctional Service shall establish and run, in designated Custodial Centres, industrial centres equipped with modern facilities for the enhancement of vocational skills training for inmates aimed at facilitating their reintegration into society (Nigerian Correctional Act, 2019).

However, Chikwelu et al. (2018:1) succinctly avowed that:

It is expected that when a law offender is incarcerated. He or she would be reformed or re-socialized to behave in a socially approved manner that could enable him or her to reintegrate back to society. It is also expected that the prison system would be effective in correcting the antisocial behaviours which are responsible for the imprisonment of certain individuals. However, this expectation may be probable in the Nigerian prison context.

Apparently, in Nigeria, it appears that the mandate of reforming convicts by the Correctional Service has been defeated very long ago. This observation is not only hinged on the public perception of the institution, but on the reality in Nigerian society. The general view of the correctional centers is somewhat of hell an institution coupled with societal stigma accompanying an ex-convict even after serving the jail term. The public conclusion is the moment a judgment is preferred on a person with the last sentence being, 'after careful examination, you are hereby sentenced to so- and-so period', the people's interpretation of the statement is that all hope is lost, and the individual sentenced to eternal condemnation. An attendant fact to the above view is not too divergent observation that many of the ex-convicts who after serving the compulsory jail term, gained freedom, yet, they continue to constitute a nuisance, menace and pose threat to the peace and tranquility of the society. Due to this addiction, 
many of them even go back to prison after violating the rules and regulations. With these scenarios, it does appear the number of years behind bars has not had much of an impact on them rather; it has become a futile and wasted experience.

Enthrallingly, in 2019, the Nigerian government came up with the rebranding, reforming and repositioning the institution to meeting modern correctional institutions. Part of this policy invariably led to the change of name from Nigerian Prison Service (NPS) to Nigerian Correctional Service (NCS). However, a close shave and look at the institution suggest an event of putting 'old wine in a new bottle'. That is, the institution has in the past and even now has all its focus on the punishment and deterrence aspect of the mandate leaving out the most important aspect (reformation and rehabilitation) which has to do directly with the society. According to Ugwuoke (2010, cited in Chikwelu et al. 2018:1) punishment continues to be an integral aspect of the Nigerian prison system over and above the rehabilitation, reformation and reintegration of prison inmates. It is against this scenery in Nigeria and the global importance of reformation that the paper critically examined the Nigerian Correctional Service with emphasis placed on its effectiveness at reforming and preparing inmates for life after incarceration. The trust is thus established on the ground that to address a social malaise, it is required to undertake a holistic institutional transformation rather than the peripheral or dissection analysis of parts. The idea is to guarantee that the entire society is saved from being infiltrated by the trend on an incommodious range.

\section{Methods}

In a bid to interrogate, cross-examine and comprehensively dissect the debacle rumbling correctional institution in Nigeria, the study made use of qualitative method. However, the research design used for the study was anchored on descriptive expedition as the phenomenon under investigation could not have been properly explored and complete description of the state of affairs were made possible through the application of this method (Fox \& Bayat, 2007). Therefore, for the data collection, the study fetched data through secondary source. Hence, literature materials were carefully examined by tracing written materials from sources such as books, journals, magazines, periodicals, conference papers, mass media reports and other materials found useful to the study. Also, some internet resources related to the study were used and 
vivaciously added impetus to the inquiry. Furthermore, content analysis was carried out. The sequence of data analysis started with organising data, sorting through it, looking for and finding patterns, presenting data and deducing a valid conclusion became pretty easy.

\section{Results and Discussion}

The historical background of the Correctional institutions in Nigeria, formerly referred to as Nigerian Prison Service could be incomplete without tracing it to the pre-colonial era. This has to do with the fact that among the major ethnic groups and even the lesser groups in Nigeria, though raw in a sense, there had been recognition and establishment of prison centre or building meant to house the lawbreakers. For instance, Ikoh (2011:2) observed that:

In pre-colonial Nigeria, history has told us about the availability of prisons, where people who deviated from the societal norms and values were either kept for trial or punishment. Among the Yoruba's, there was a prison system in ogboni House. In Tiv land, a building was set aside in the chief's compound for offenders. There existed the Ewedo in Benin Kingdom and the Gidan Yari among the Hausa-Fulanis.

It is said that the modern prisons in Nigeria started when western-type prison was first established in 1861 and also coincides with the declaration of Lagos as a colony coupled with the establishment of the police force and court system in 1863 unavoidably laid credence for prison establishment. According to the publication of Prisoners' Rehabilitation and Welfare Action (PRAWA) (2017 pp.1-2):

The establishment of a police in 1863 the same year and four courts in 1863 to try sundry offences made the existence of prisons inevitable. This led to the setting up of the Broad Street prison (now christened, "Freedom Park") in 1872 with an initial inmate capacity of 300 . However, by 1910, due largely to an explosion in commercial activities, there already were prisons in Degema, Calabar, Onitsha, Benin, Ibadan, Sapele, Jebba and Lokoja.

With the successful amalgamation of the Southern and Northern protectorates in 1914, by the British government, prisons establishment was solidified with variance of native authority prisons, provincial prisons, and maximum-security prison located in places like Enugu, Kirikiri in Lagos, 
Owerri, Onitsha, Ogoja, Nsukka, Okitipupa, Kano, Uyo and others. With the termination of colonial rule and attainment of independence in 1960, it behooved on the Nigerian government to establish the Nigerian Prison Service. In 1972, Retired General Yakubu Gowon issued Decree No. 9 establishing and clearly defining the functions and responsibilities of prisons in Nigeria, the Decree was later changed to Prison Act 1990. However, with the reforms carried out in 2019, apart from the name change from Prison Service to Correctional Service, the Nigerian Correctional Service Act repealed the existing Prison Act.

\section{Theoretical Scaffold}

Establishing a justification and theoretical base for correctional institutions, the study adopted two theories: The Deterrence theory of punishment and the Rehabilitation theory of punishment. These theories are germane to the study because the underlining idea of correctional institutions entails two things; punishment and rehabilitation of convicts.

\section{Deterrence Theory of Punishment}

The deterrence theory of punishment is associated with the works of classical philosophers like Thomas Hobbes, Cesare Beccaria and Jeremy Bentham. As the name of the theory implies, criminals wouldn't choose to break the law after thoughtfully considering the punishment that goes with their actions. In essence, the idea of punishment influenced and underscored the deterrence theory. This simply means that severe punishment must take its cause whenever criminal acts are committed. According to Anzaku et al. (2015:2) by sentencing criminals to extremely harsh penalties, other people who might be considering criminal activities will be so terrified of the consequences that they will choose not to commit crimes out of fear. In a similar standpoint, Onwudiwe et al. (2011:254) noted that, since people are rationally self-interested, they will not commit crimes if the costs of committing crimes prevail over the benefits of engaging in undesirable acts.

From the above views as expressed by these scholars, it could be deduced that the idea of incarceration and the swift punishment that accompanies it, is not only a measure to deter offenders or dissuade would-be offenders, but to also keep the society going at the expense of both convicted and potential lawbreakers. However, due to the non-encompassing nature of the theory, that is, only the penal aspect was emphasized on without provision for the 
psychotherapy aspect, and the changing trends in penal administration which in the 21st century is centered more on rehabilitation than chastisement, hence the need for rehabilitation theory of punishment.

\section{Rehabilitation Theory of Punishment}

The rehabilitation theory of punishment gained prominence in the 20th century and of course, very much in force in the 21st century. The theory has its root in the utilitarian philosophy. The central argument of the theory is that, though punitive measures are needed for crimes committed in the society but they have consequences on both the offenders and the society, therefore, the goods produced by the punishment on the offenders and the society have to outweigh the impiety done to both. Put differently, the reason for incarceration should not be solely focused on maltreatment or punishment alone; it has to also make them better persons who would not pose a further threat to society. Anzaku (2015:3) observed that:

Under the rehabilitative theory of punishment, the essential element of focus is treatment. Treatment in the sense of working with the individual in such a way that he will be able after a prolonged programme of training or treatment so-called to make a satisfactory adjustment to conventional lifestyle once he is released from official custody.

In tandem with the ultimate goal of rehabilitation which is meant to avert crime in the future by preparing them with the opportunity to compete and excel in the larger society after the expiration of their confinement. Though, it is often done within the ambit of law through measures like mental or psychotherapy treatment, exposure to educational programmes that can imbue them with the knowledge needed to impact significantly the society most especially after expiration of jail term, and encouragement of vocational or entrepreneurial skills to make them self reliant, thereby contributing to the growth of their immediate society. According to McNeill (2014:3):

Correctional rehabilitation is concerned with effecting positive change in individuals. As such it is the model most commonly associated with treatment programs or other forms of offence- or offender-focused intervention. At its heart is the notion that many offenders can change for the better, given the right support. The idea of correction implies that the offender can and should be 'normalised'or're-socialised' in line 
with commonly accepted (though rarely explicitly articulated) standards of behaviour.

\section{The Awful Condition of Nigerian Correctional Centres and Rehabilitation}

Starting this section with one of the beautiful quotations of former South Africa President, Nelson Rolihlahla Mandela, who was incarcerated for a whopping 27 years, he said; 'No one truly knows a nation until one has been inside its jails'. He went further and asserted that 'a nation should not be judged by how it treats its highest citizens, but its lowest ones' (Williams, 2019). The forgoing quote pictorially captured the reality of how outsiders judging Nigeria without prior knowledge of its prisons or correctional centres. Shedding light on the scenery conscientiously, Ojeah (2020) argued that 'the abysmal state of prisons nationwide has been a decades-spanning matter of great concern. These correctional centers tell tales of dilapidated and overcrowded cells, terrible sleeping conditions, barely edible meals lacking in essential nutrients and an absence of clean flowing water'. Ajah (2018:4) wittingly quips that Nigeria prisons are worse than hell. He was led to this analogy because many of the prisons are older than the nation itself. He further accounted that:

The facilities are not upgraded yet, the inmates sent there are far more in population than the facilities were designed to accommodate. Inmates are crammed; sanitary facilities are simply inhuman, diseases are freely shared, yet, more inmates are daily brought in to compound the already bad situation (Ajah, 2018:4)

The Nigerian Correctional Service, though guided by the Correctional Act of 2019 which repealed the long-existing Prisons Act of 1990.The institution is also compliant with the International Human Rights standards and good correctional practices and United Nations Standard Minimum Rules for the Treatment of Prisoners, christened (The Nelson Mandela Rules). The subscription is because the nation is an active and signatory member of the United Nations. Apart from this, the reformation that led to the change of name from Prison to Correctional service via the President's assent of the Nigerian Correctional Service Act in August 2019 is also a determinant factor in this regard.

However, this appendage should not be misconstrued as been easily facilitated or come by; it was the persuasion through the actions and voices 
mounted by civil society groups, Non-governmental Organizations (NGOs), religious organizations, intellectuals and concerted human rights activists which had long trailed the Nigeria's Criminal Justice dispensation and against the deplorable condition and treatment of inmates in Nigerian prisons seems to have finally paid off. The interpretation of anyone reading on the Prison reforms that took place in 2019 is that everything that has to do with the institution has fallen in shape, normalized and regularized. It is however pertinent to note that though there are changes as regards name and some other things within the system, yet, visibly enough are the sorry state of welfare of convicted and inmates awaiting trial.

A conundrum was on Thursday, April 9, 2020, made public by the Comptroller General of Nigerian Correctional Service, Ja'afaru Ahmed, when he gave a figure which indicated that 51,983 inmates are awaiting trial out of the prison's total population of 73,726 inmates which is about 70 percent of the total population of inmates or three-quarters of Nigeria's total prison population (Premium Times, April 10, 2020). Within five months from when the statistics were given by the Comptroller General, the institution released another statistics consolidating the earlier assertion. According to the statistics, 'as of 26th October 2020, the total number of convicted prisoners nationwide was 16,662 deciphering 26 percent while the total number of prisoners awaiting trial was 48, 155 translating 74 percent' (Nigerian Correctional Service, 2020). The import from the above official reports from the Comptroller General and the institution is that Nigerian correctional centres are not only overstressed with a high number of people awaiting trial but also keep captive of innocent citizens at the expense of criminals. Pragmatically, all of these shortcomings point to the weak Criminal Justice dispensation in the country. For Onyeji \& Udegbunam of Premium Times:

A report by Nigeria's National Bureau of Statistics covering data from 2011 to 2015 , shows that $72.5 \%$ of Nigeria's total prison populations are inmates serving time without being sentenced, and spotting flaws in Nigeria's criminal justice system with proceedings often going on for years without conclusion. While lengthy court proceedings are an obvious problem, the figures in the NBS report also highlighted a worrying culture of arbitrary arrests by Nigerian law enforcement agencies (Premium Times, April 10, 2020).

Apart from the inconsistent criminal justice system, the deplorable state 
of facilities at the correctional centres and lack of awareness of what a 21stcentury correctional institution ought to be on the part of staff are two-fold problems the system is currently enmeshed with. Numerous scholars have in the past highlighted these seemingly perennial problems in the institution. One of such scholars' views on the terrible welfare of both personnel and prisoners plus the infrastructure put in place is that of Erinosho (1999 cited in Ikoh, 2011:5) who observed that prison workers are poorly uninformed, poorly paid, while prisons lack the resources needed to promote the welfare of inmates. Remarking on the worrisome condition of prison infrastructures hosting inmates in Nigeria, Ogundipe (2006 cited in Ajah \& Nweke 2017:362) argued that, its infrastructures and logistics have experienced centuries of neglect that have made the Prisons at this time be a moral equivalence of hell.

If worries about the level of infrastructures and logistics at various correctional centres could be as alarming as quantifying it with hell, only God knows what would qualify as an equivalence of the level of diet (food), medical services, water supplies, clothing and other basic needs inmates should have right to. This deprivation having existed for so long and even retained despite the purported reformation of the institution in 2019, it does appear that Nigerian Correctional Service is condemned to have all its focus fixed on the punitive and penal aspect with little or no place for reformation and rehabilitation of offenders. There is no gainsaying that jail management in the 21st century has since moved from punishment of offenders to reforming and reintegrating them back to the conventional society. Ajah (2018:300) remarked that:

There is more to imprisonment than the opening and closing of prison gates modern penal management techniques emphasize reform of the inmate. The current attitude is to see imprisonment from the perspective of reform and rehabilitation rather than from the perspective of punishment. It is assumed that those who have committed crimes need help and should be assisted to live a good life.

In Nigeria, the true sense of rehabilitation has long remain an irony, even with the reform and number of initiatives captured in the Nigerian Correctional Service Act 2019 meant to reposition the institution for a better and efficient service delivery, this flaw has not been rectified. One begins to wonder if the reform of such monumental magnitude is expressly fine-tuned at addressing only the name of the institution at the expense and detriment of issues and concerns that the attention of the government. The submission 
became necessary because as a matter of verity, there has only been a change of name and also uniform of personnel. Without any contradiction incur, the nittygritty of why such reforms should have been carried out has been conspicuously missing. In other words, the much-publicized reform has not brought holistic changes to the institution. In an attempt to de-congest correctional centres, the President through the Minister of Interior, Ogbeni Rauf Aregbesola exercised the prerogative of mercy by setting some convicted and individuals awaiting trial free, though, a kind and laudable gesture from the President.

With the reforms recently carried out, one would have expected that the reforms should have led to the drastic reduction of inmates in the correctional centres. Astonishingly, there still exists a high level of congestion in various correctional centres across the nation. The Port Harcourt prison, for instance, built to accommodate 800 inmates, had over 4, 000 inmates occupying its cells as at August 2019. Similarly, Kirikiri Maximum Prisons, with the capacity to hold only 956 inmates held about 2, 600 also as of August 2019. Though the congestion is not solitarily occasioned by the high number of people awaiting trials, but as a result of prison facilities are overstressed (Ojeah, 2020). Almost two years after the purported reformation/revamping of the correctional institution, there lingers the problem of congestion. Making this fact known on July 23, 2021, Nigeria's Minister of Interior, Ogbeni Rauf Aregbesola, concord with this reality and subsequently promised to ensure a drastic decongestion of inmates across various correctional facilities as most facilities have been overpopulated to the brim. In his words, 'the entire capacity of the custodian facilities is 57,278 but had 68,778 inmates which made the facilities overpopulated and overstretched in the cities' (Nigerian Correctional Service, 2021).Given this recurrent anomaly that continues to pan out in the system even after the 2019 reformation exercise, it therefore becomes needless to emphasize that such an environment will be uncomfortable and can readily give rise to disease spread among inmates. Not that alone, one could also doubt the type of rehabilitation taking place in such correctional centres.

As a result of poor rehabilitation programmes obtainable in Nigeria correctional centres which has certainly given rise to an increase in cases of recidivism in the system. Alamu \& Makinde (2019:62) argued that the rate of recidivism, that is, ex-convicts returning to prison is becoming alarming and a daily occurrence in Nigeria. The duo went further to aver that, prison officers now have second-time and serial offenders in the system to deal with. This surge cannot be said to be unrelated to the fact that while in the correctional 
centres, convicts have not been adequately exposed, educated and imbued with the skills needed to earn a daily living after serving their jail term. With the vital condiment of rehabilitation missing, many of the convicts rather than becoming law abiders after a long period of incarceration unsurprisingly become arrant and unrepentant criminals. To put the final nail on the coffin, Alamu \& Makinde (2019:62) observed that, rehabilitation of prison inmates has not affected them, as convicts became affected and dangerous contrary to societal expectations of rehabilitated individuals.

Bearing in mind that not too long, the federal government of Nigeria carried out reformation of the correctional service and yet the statuesque remain in that it has not translated to institutional transformation capable of making convicts or reformed individuals that would comply with societal norms and laws. To however quest a bit more is to ask these few questions begging for answers; could it be that the reformation wasn't institutional-based? Or could it be that wholehearted implementation has been forgotten the moment the institution's name was changed? And better still, that the implementation has been at a snail speed as a result of a lack of commitment and political will on the part of the government, a common trademark of government which have been plaguing nearly all of human spheres in the nation for years.

\section{Conclusion}

Inmates, whether convicted or awaiting trial kept in jail for so long without an appreciable measure of rehabilitation, could be more dangerous to society than the potential or would-be offenders who have not been caught. Knowing full well that it is the true sense of what operates in the correctional centres nationwide; a time bomb waiting to explode and capable of consuming the entire society if not detonated on time. To address this, the paper therefore appraised the correctional institution in Nigeria, the purported reformation recently carried out in the establishment coupled with the preparedness of the institution to shift grounds and embrace rehabilitation as its core function as against the visible retribution currently in place. Findings show that formulations and conjectures of ideas meant to improve the institution; staff and inmate's welfare are not the concern, but the problem lies somewhere in the heart of willful implementation. However, because Nigeria is such a society whereby after identification of traditional lopsidedness or a societal malady and with public outcry trailing, the government does little to dowse the tension at the very hot peak, that moment also signifies the end of any reasonable effort by 
the government towards its curtailment. So, carrying out further research about the phenomenon which would enable them to combat future occurrence or similitude issues that might spring up at no given time has never been a priority. Owing to this syndrome, the paper concludes that to lessen the number of outcries on the institution, the reformation exercise was initiated and carried out to address trivial issues like staff uniform change, name change and leaving out the core, most important and the nitty-gritty of the institution unchanged.

\section{References}

Ajah, B.O. \& Nweke, J.O. (2017). Prison facilities and the welfare of inmates in Nigeria: A case study of Abakaliki and Awka Prisons. World Applied Sciences Journal. 35(3). 361- 369.

Ajah, B.O. (2018). Educational training of inmates in Awka and Abakaiki Prisons. Nigeria International Journal of Criminal Justice Sciences. 13(2). 299. 305.

Ajah, B.O. (2018). Criminal justice administration and panic of prison correction in Nigeria. Journal of Law and Judicial System. 1(2). 1-8.

Alamu, I. O. \& Makinde, W.A. (2019). Challenges to effective implementation of rehabilitation programmes for prison inmates in Southwestern Nigeria: An empirical approach. Canadian Social Science. 15(9). 61-68.

Anzaku, S.A. Ismaila, G. A. Agube, S.A (2015). The theoretical exploration of punishment and incarceration in Nigeria? Research Journal of Humanities and Cultural Studies. 1(8). 1-6.

Chikwelu, N.E. Ajah, B.O. Obiefuna, C.E. Egbegi, F.R. (2018). Correctional programmes within the prison community: The views and perception of inmates and staff in Anambra State Prisons, Nigeria. Developing Country Studies. 8(6). 1-7.

Fox, W. \& Bayat, M.S. (2007). A guide to managing research. Juta Publications.

Ikoh, M.U. (2011). The Nigerian prison system and the failure of rehabilitation: An examination of incarceration alternatives. Nigerian Academic Forum. 20(1). 1-8.

McNeill, F. (2014). Punishment as rehabilitation. In: Bruinsma, Gerben and Weisburd, David (eds.) Encyclopedia of criminology and criminal justice. Springer.

Nigerian Correctional Service Act (2019). https://lawnigeria.com (accessed 15 
Journal of Social Studies (JSS), Volume 17, Number 2, 2021: 241-254

April, 2020).

Nigerian Correctional Service (2020). https://interior.gov.ng/nigeriacorrection-service (accessed 26 May, 2020).

Nigerian Correctional Service (2021). FG poise to ease congestion in correctional centres, https://interior.gov.ng/press-release/fg-poise-to-ease-congestionin-correctional-centres/ (accessed 10 April, 2020).

PRAWA. (2017). Nigeria's awaiting trial prisoners. Penal Reform Fact Sheet. 1(1). $1-7$.

Onyeji, E. \& Udegbunam, O. (2020, April 10). '70\% of Nigerian prisoners held without trial'. The Premium Times. https://www.premiumtimesng. com/ (accessed 7 May, 2020).

Obioha, E.A. (2011). Challenges and reforms in the Nigerian prisons system. Journal of Social Science. 27(2). 95-109.

Ojeah, M. (2020) 'Prison Reform in Nigeria' https://www.manifieldsolicitors. com (accessed 6 March, 2020).

Onwudiwe, I.D., Odo, J. \& Onyeozili, E. C. (2011). Deterrence theory https:// marisluste.files.wordpress.com/2010/11/deterence- (accessed 7 May, 2020).

Shajobi-Ibikunle, D.G. (2014). Challenge of imprisonment in the Nigerian penal system: The way forward. American Journal of Humanities and Social Sciences. 2(2). 94-104.

Williams, J.L. (2019). 'Beyond the Nigerian correctional services act', https:// www.cfr.org/blog/beyond-nigerian-correctional-services-act (accessed 5 May, 2020). 